\title{
Effect of solar ultraviolet radiation on the formation of shallow, early successional biofouling communities in Hong Kong
}

\author{
Sergey V. Dobretsov ${ }^{1}$, Pei-Yuan Qian ${ }^{1, *}$, Martin Wahl ${ }^{2}$ \\ ${ }^{1}$ Department of Biology and Coastal Marine Laboratory, Hong Kong University of Science and Technology, Clear Water Bay, \\ Kowloon, Hong Kong SAR \\ ${ }^{2}$ Institute for Marine Sciences, IFM-Geomar, Düsternbrooker Weg 20, 24105 Kiel, Germany
}

\begin{abstract}
The effect of ambient solar ultraviolet radiation (UVR) on a shallow-water $(4 \mathrm{~cm})$ tropical fouling community was assessed during the succession of macrobenthic species on artificial substrates at the Wong Shek fish farm, Hong Kong. The early successional communities developing under 3 radiation treatments (PAR + UV-A + UV-B $=280$ to $700 \mathrm{~nm}$; PAR + UV-A = 320 to $700 \mathrm{~nm}$, and PAR $=400$ to $700 \mathrm{~nm}$ ) were monitored for $14 \mathrm{wk}$. A total of 8 species of algae and 8 species of invertebrates colonised the experimental tiles. During the first $8 \mathrm{wk}$ of the experiments, there were no differences among treatments in diversity, percentage of cover of species and the biomass of the colonisers. During the following $6 \mathrm{wk}$, the communities exposed to UVR had lower species richness than the communities exposed to only PAR had. The species diversity (after 79 and $98 \mathrm{~d}$ ) of the 3 treatments varied, but the total percentage of species cover and the entire community biomass were not significantly different across the experiment. Juveniles of the polychaete Hydroides elegans and the barnacle Balanus amphitrite, juveniles of the clams Perna viridis and Modiolus comptus, and the algae Enteromorpha sp., Ectocarpus sp. and Cladophora sp. were responsible for the dissimilarity between communities developed under different UVR treatments. The algae constituted a higher percentage of the cover under the full sunlight spectrum, whereas the polychaete, the barnacle and the clams were dominant in the no-UVR treatment. Our outdoor experiment revealed that UVR inhibited the settlement and decreased post-settlement survival of $H$. elegans. We concluded that UVR affects the composition of early successional, shallow water biofouling communities in tropical waters as well as the settlement and mortality of single species.
\end{abstract}

KEY WORDS: UV-A · UV-B · UV stress · Biofouling communities · South China Sea · Community structure $\cdot$ Recruitment $\cdot$ Larvae

Resale or republication not permitted without written consent of the publisher

\section{INTRODUCTION}

Since the discovery of the depletion of the earth's ozone layer in the earth's atmosphere and the corresponding increases in solar ultraviolet radiation (UVR), many investigations have focussed on the potentially harmful effect of UVR on the biota in terrestrial, freshwater and marine environments (e.g. Bornman \& Teramura 1993, Willamson 1996). UVR may damage organic molecules (i.e. DNA, RNA) and cause inhibition of photosynthesis (Bailey et al. 1983, Franklin \&
Foster 1997, Wiencke et al. 2000). In addition to effects on primary production, UVR may affect species composition and species interactions in communities, which may lead to changes in community structures and ecosystem functions (Bothwell et al. 1993, 1994, Searles et al. 2001). It is possible that individuals damaged by UVR will be more vulnerable to predators, which in turn will affect their community structures (Lotze et al. 2002). It has been suggested that individuals in the adult phase of their life cycles may be more resistant to UVR than those in the larval or juvenile 
phases (Baker 1995). In a laboratory study, UV-A and UV-B radiation damaged embryos, larvae and juveniles, but not adults of the solitary ascidian Corella inflata (Bingham \& Reitzel 2000). UV-B radiation also reduced survivorship of larvae of the bivalve Dreissena polymorpha (Chalker-Scott et al. 1992); both UV-A and UV-B radiation inhibited the settlement of planulae of the coral Pocillopora damicornis (Baker 1995, Kuffner 2001) and strongly impaired the germination of algal zoospores (Santas et al. 1998a, Wiencke et al. 2000). Inhibition of larval settlement and recruitment, as well as poor survival of juveniles, caused by UVR exposure might ultimately alter species composition of benthic communities.

Knowledge about UVR effects on benthic communities and species interactions in the oceans is scant. Most investigators study the effect of UVR on single species (e.g. Baker 1995, Bingham \& Reitzel 2000, Chiang et al. 2003). Only a few studies have examined the effect of UVR on benthic communities (Santas et al. 1998a,b, Lotze et al. 2002, Molis et al. 2003, Molis \& Wahl 2004). For example, Santas et al. (1998b) investigated the effect of UV-A and UV-B radiation on benthic diatoms in a coral reef in the Caribbean. They demonstrated that early successional communities exposed to the full spectrum of solar radiation had lower productivity than had communities exposed only to photosynthetically active radiation (PAR) with UV-A. Diatom diversity differed among treatments, because 7 species of diatoms were sensitive to UV-B. Analogously, in Nova Scotia (Canada), UVR decreased the biomass and species cover of the benthic communities (Lotze et al. 2002). The effect of UVR on the biofouling communities in tropical waters has not yet been investigated.

In tropical waters, the colonisation and succession of biofouling communities are very rapid (Huang \& Mark 1982, Huang et al. 1999, Qiu et al. 2003, Dobretsov et al. 2004). Larvae begin attaching to artificial substrates within hours of the substrates being submerged. In Hong Kong's coastal waters, the biomass of the fouling community may reach 30 to $50 \mathrm{~kg} \mathrm{~m}^{-2}$ within a few months (Huang \& Mark 1982). The shallow-water fouling community is dominated by the tube worm Hydorides elegans (Wang \& Huang 1993, Qiu et al. 2003). Therefore, we expect UVR to affect the fouling communities in the shallow waters near Hong Kong. In laboratory experiments, a UV-B radiation dose of $28 \mathrm{~kJ}$ $\mathrm{m}^{-2}$ reduced the recruitment of an intertidal fouler, the barnacle Balanus amphitrite (Chiang et al. 2003, Hoag 2003). A UV-B radiation dose of $7.2 \mathrm{~kJ} \mathrm{~m}^{-2}$ caused significant damage to the rhabdomeres (the photoreceptor cells) in the naupliar eyes of barnacles, thereby changing larval behaviour. However, the effect of UVR on the recruitment and post-settlement mortality of the subtidal fouler $H$. elegans has not been investigated so far.

The aims of the present study were (1) to investigate in the field the effect of ultraviolet radiation (UV-A and UV-A + UV-B) on the percentage of cover, the Shannon diversity, the species richness and the biomass of early successional macrofouling communities; (2) to investigate the effect of UVR on the larval settlement of the major fouler, the polychaete Hydroides elegans, and the post-settlement mortality of $H$. elegans in an outdoor experiment; and (3) to compare results of both the field and outdoor laboratory experiments.

\section{MATERIALS AND METHODS}

Field experiment. Experimental site: This study was conducted near the Wong Shek fish farm, South China Sea, Hong Kong $\left(22^{\circ} 25^{\prime} \mathrm{N}, 114^{\circ} 20^{\prime} \mathrm{E}\right)$, from 14 June to 3 September 2001 . The study area is characterised by a tidal amplitude of 0.5 to $2.5 \mathrm{~m}$. The water temperature and salinity during the study period varied from 24 to $29^{\circ} \mathrm{C}$ and 20 to $34 \mathrm{psu}$, respectively. The large number of nets and buoys fouled by sessile organisms at the site ensured an abundant larval supply from many species.

Raft construction: Fouling communities were studied on unglazed brown ceramic tiles $(7.5 \times 7.5 \mathrm{~cm})$. Each tile was fixed inside a translucent plastic box $(16 \times 16 \times 7 \mathrm{~cm})$ (Fig. 1). The sides were constructed with a $5 \times 5 \mathrm{~cm}$ opening, which allowed larvae to enter the box and did not alter the flow regime. Preliminary experiments demonstrated that boxes constructed with these openings did not alter the formation of fouling communities, which was the same on tiles not placed in boxes but exposed to fouling. The ceramic tiles were attached by tape to the centre of the box, which allowed us to remove the tiles periodically for measuring and cleaning. The lid of each box had an aperture $\left(10.5 \times 10.5 \mathrm{~cm}^{2}\right)$ that was either covered by a filter $\left(12.5 \times 12.5 \mathrm{~cm}^{2}\right)$ with different UV-absorbing properties (treatment) or was left uncovered (open). Four boxes subjected to different treatments (see below) were placed on an experimental raft in 2 rows (Fig. 1). There were 6 replicated rafts in the experiment. All ceramic tiles were held at a depth of $4 \mathrm{~cm}$. The frame of the experimental raft $(50 \times 730 \mathrm{~cm})$ was made from PVC pipes (3 $\mathrm{cm}$ diameter), and junctions between pipes were bound with water-resistant glue. Air trapped inside the pipes provided buoyancy. Additional buoyancy was achieved by filling the space between the pipes and boxes with polystyrene foam (Fig. 1). After $4 \mathrm{wk}$, the supplemental buoys were attached to the raft to compensate for the increasing weight of the fouling communities. Rafts were situated 


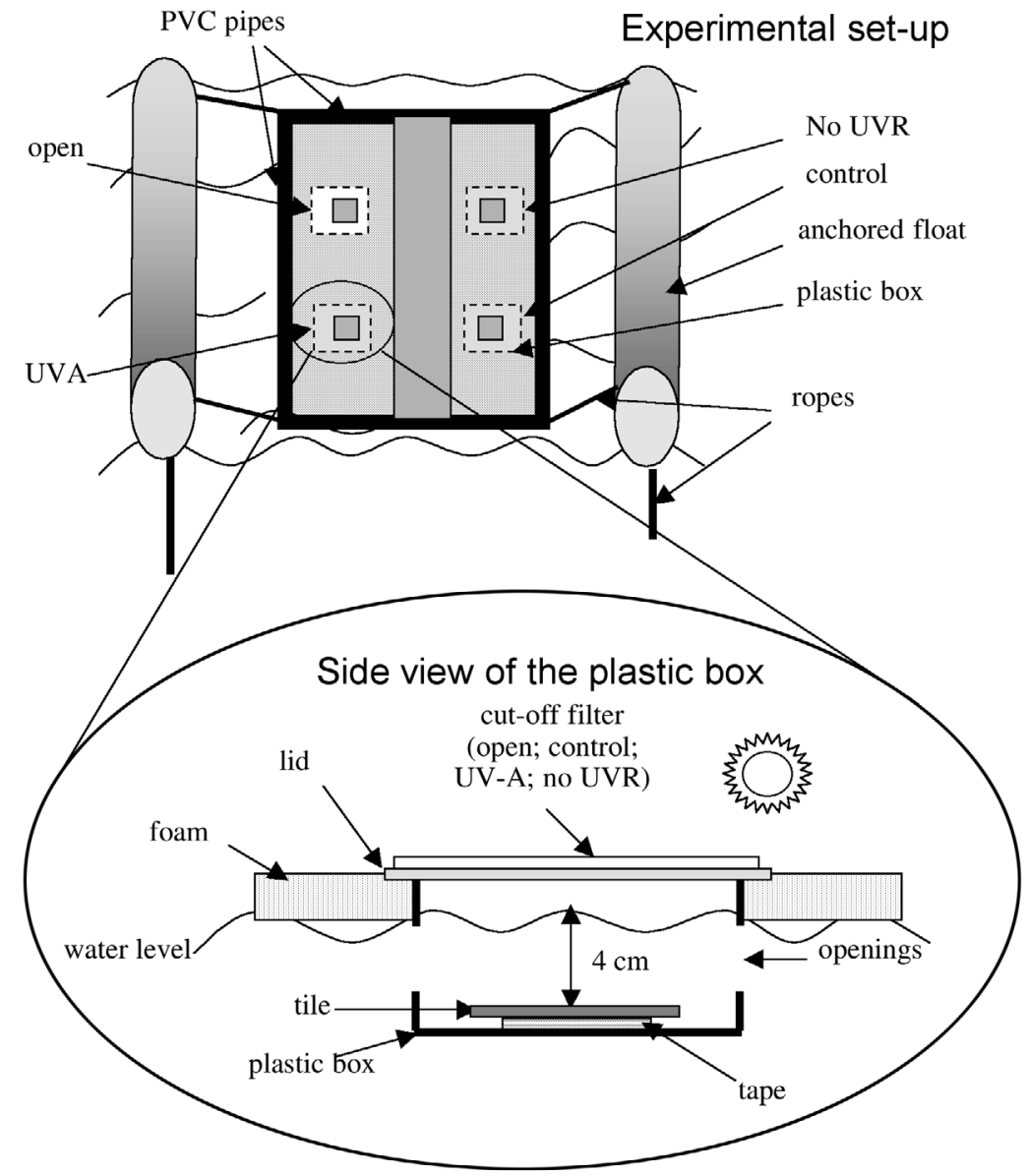

Fig. 1. Schematic view of the experimental raft and the plastic box used in the experiments

transmission due to salt spray and fouling, all filters were cleaned with a soft cleaning sponge at least twice a week.

UVR measurements: UVR measurements were taken every sunny day (a total of $41 \mathrm{~d}$ ) of the study period (Fig. 3). All UVR readings were taken at approximately noon local time (11:30 to $12: 30$ h), with sensors measuring the radiation simultaneously above the water surface and $4 \mathrm{~cm}$ below the surface; 2 broadband sensors (Gröbel UV-Elektronik) for UV-B (280 to $320 \mathrm{~nm}$ ) and UV-A (320 to $400 \mathrm{~nm}$ ) were used. Each measurement lasted 15 to $16 \mathrm{~min}$; the average UV irradiance $\left(\mathrm{W} \mathrm{cm}^{-2}\right)$ was then calculated.

Analysis of field data: We analysed macroscopic species composition on the tiles after 17, 37, 56, 79 and $98 \mathrm{~d}$ of the experiment. To reduce the risk of edge artefacts, no data were collected from a $12 \mathrm{~mm}$ wide margin on the outside edges of each tile, leaving $25 \mathrm{~cm}^{2}$ of substratum for analysis. From this area, 3 fields of vision of $1 \mathrm{~cm}^{2}$ were randomly chosen for the counting procedures. This randomisation procedure was used for each count. All species both $>2 \mathrm{~mm}$ in length and cumulatively occupying $>1 \%$ of the tile were counted, and the mean percent cover for each species on the tile was estimated and used for subsequent statistical analysis (see below). Starting on the Day 79 of the experi-

in 3 rows, and the distance between separate rafts was 4 to $10 \mathrm{~m}$.

UVR treatments: The effect of UVR on the development of the fouling community was tested in a randomised block design (Underwood 2001). Different types of transparent polycarbonate sheets (Figs. 1 \& 2) were used to create the 3 different radiation treatments. For the no-UVR treatment, we used $4 \mathrm{~mm}$ thick Macrolon sheets (Long Life Plus 293, Röhm) that filter out UVR (290 to $400 \mathrm{~nm}$ ), but allow $90 \%$ transmission of PAR (Fig. 2). The UV-A treatment (320 to $700 \mathrm{~nm}$ ) was obtained using the combination of $3 \mathrm{~mm}$ thick Perspex filters (GS 2648, Röhm) and $1 \mathrm{~mm}$ thick polyester film (PP 2500, 3M) (Fig. 2). The polyester film was replaced every month. The control boxes (PAR + UV-A + UV-B treatment) were covered with $3 \mathrm{~mm}$ thick Perspex filters (GS 2648, Röhm), as these filters do not block transmission of solar UVR or PAR (Fig. 2). Boxes without filters (open) in comparison with the PAR + UV-A + UV-B treatment served as a control for the filter artefacts. To minimise the possible reduction of ment, algae grew so intensively on the tiles that water exchange in the box was reduced. We cut the algae back to a length of $1 \mathrm{~cm}$ and weighed the algae separately; the percentage of cover for each species on the

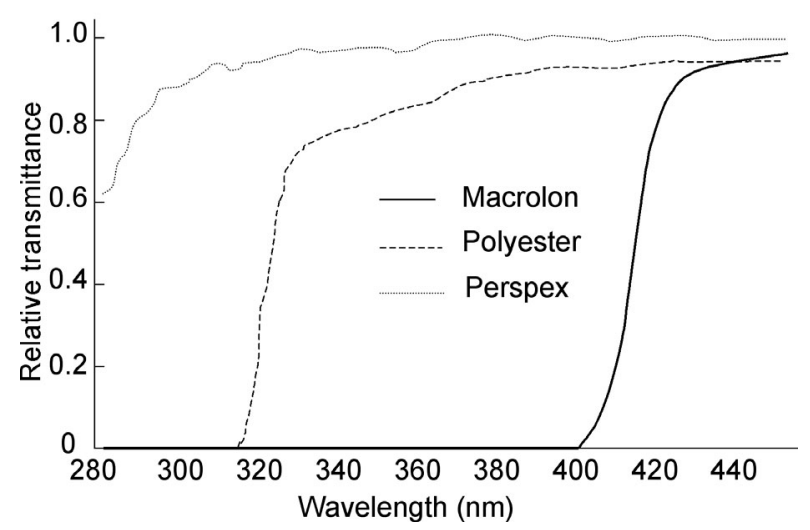

Fig. 2. Optical properties of cut-off filters used in the experiments (Perspex: PAR + UV-A + UV-B [control]; Perspex + Polyester: PAR + UV-A [UV-A]; Macrolon: PAR only [no UVR]) 

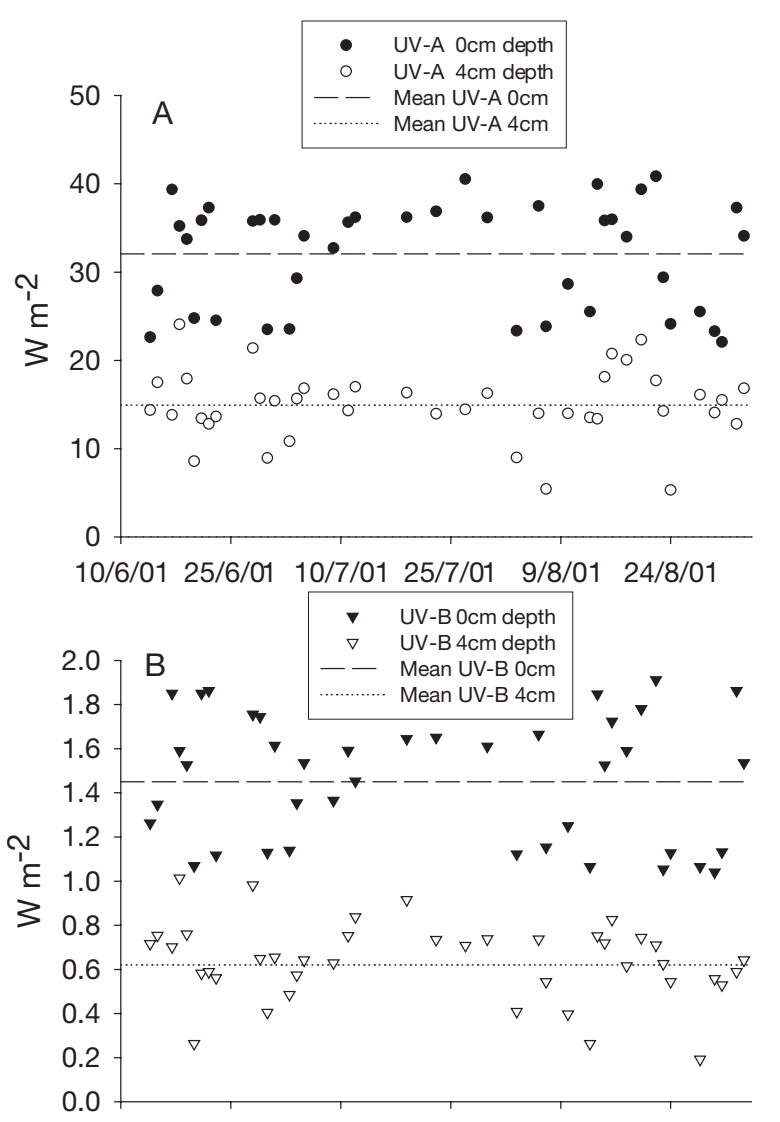

10/6/01 25/6/01 10/7/01 25/7/01 9/8/01 24/8/01

Time of experiments

Fig. 3. Mean solar radiation (A) UV-A and (B) UV-B ( $\mathrm{W} \mathrm{m}^{-2}$ ) at noon (local time) measured every sunny day at the surface and at a depth of $4 \mathrm{~cm}$

tile was determined after the algae were cut back. The wet weight of species on the whole tile was measured regularly. To take this weight, we held the tiles vertically for 1 min to allow the water to drain, and then the weight of the tile was recorded on a portable balance (Model 323, Bonso Electronic International). The weight of each wet tile was measured before the start of the experiment and was subtracted from obtained wet weights. At the end of the experiment, the dry weight of the fouling community was measured after scraping all organisms from the tiles and drying them at $70^{\circ} \mathrm{C}$ for $3 \mathrm{~d}$. The tiles did not measurably alter during experiments, because their weights at the end of experiments did not differ from their weights at the start of experiments.

To measure diversity of the fouling community under the different UVR treatments, the Shannon-Wiener $H^{\prime}$ diversity index and Margalef's species richness measure were calculated using the PRIMER 3.1 software from Plymouth Marine Laboratory (Clarke \& Gorley 2001). Diversity $\left(H^{\prime}\right)$, species richness, total abun- dance, as well as wet weight of the community, were compared among treatments using repeated-measures MANOVA (Zar 1996). The effects of the light (variation between treatments) and the effect of the block (variation between habitats) on the dry weights of the biofouling community, as well as their interactions at the end of the experiment, were analysed using 2-way ANOVA. Post hoc multiple comparisons were performed using Tukey's HSD (honestly significant difference)-test at the $\alpha=0.05$ significance level. Prior to analysis, percentage data were arcsine-transformed (Zar 1996). The normality assumption was verified with the Shapiro-Wilk test (Shapiro \& Wilk 1965). The effects of UVR on community structure were analysed using ANOSIM (analysis of similarity) and SIMPER (similarity percentage) procedures (PRIMER 3.1 software, Plymouth Marine Laboratory), which are based on multi-dimensional scaling (MDS) of the Bray-Curtis dissimilarity index (Clarke \& Ainsworth 1993, Warwick \& Clarke 1995).

Laboratory experiments. To investigate the effect of solar UV-A and UV-B radiation on the settlement and survival of the major fouling species in Hong Kong waters, the tube-building polychaete Hydroides elegans, under laboratory conditions and to compare laboratory data with the field results, short-term outdoor experiments were conducted.

Larval culture: Adult Hydroides elegans were collected from a raft submerged at the Wong Shek fish farm. Larval rearing procedures were the same as described by Bryan et al. (1997). Larval competence was determined both by the morphology of the larvae and by bioassay with 3-isobutyl-1-methylxanthine (IBMX, $10^{-4} \mathrm{M}$; Fluka) according to Pechenik \& Qian (1998). The bioassays were performed only with competent larvae.

UVR treatments: In the laboratory experiments, we used 3 different ambient UV treatments: for the noUVR treatment, we used the same type of $4 \mathrm{~mm}$ thick Macrolon sheets (Long Life Plus 293, Röhm) that we used in the field experiments. The control aquaria were covered using $3 \mathrm{~mm}$ thick Perspex filters (GS 2648, Röhm), as these filters do not block transmission of solar UVR or PAR (Fig. 2). Aquaria covered with a dark plastic bag (dark treatment), which blocked all visible and UVR light, served as a supplementary control.

Larval bioassay: One d experiments took place outdoors at the Hong Kong University of Science and Technology. Each of 18 small aquaria (volume $=0.3 \mathrm{l}$ ) (6 replicate aquaria per treatment) contained $100 \mathrm{ml}$ of filtered $(0.22 \mu \mathrm{m})$ seawater (FSW) and a Falcon Petri dish, which was covered with natural biofilm (NBF) developed for $7 \mathrm{~d}$ at the university pier. At the start of the experiment, 80 competent larvae of Hydroides ele- 
gans were added to each of 5 replicate aquaria per treatment; the single remaining aquarium per treatment was used for characterising the biofilm (see below). Each Petri dish was exposed to sunlight for a period of $10 \mathrm{~h}$ (from 09:00 to 18:00 h). To prevent the water in the aquaria from overheating, we placed the aquaria in a larger tank filled with fresh water that was changed hourly. UV-B and UV-A doses were measured using broadband sensors (Gröbel) once every hour of the experiment. The average UV irradiance $\left(\mathrm{W} \mathrm{m}^{-2}\right)$ for each hour was measured; afterwards, the UV-A and UV-B radiation doses $\left(\mathrm{J} \mathrm{m}^{-2}\right)$ were calculated. Metamorphosed larvae were counted under a microscope after $12 \mathrm{~h}$. Attached juveniles with developed tubes and palps were considered to have undergone normal metamorphosis. Unattached and swimming larvae were considered unmetamorphosed.

From each treatment, 1 Petri dish was used for counting the bacteria and diatoms. The biofilm in these dishes was fixed in $4 \%$ formalin solution in FSW and then rinsed with FSW. Attached bacteria were visualised with the DNA-binding fluorochrome 4,6diamidino-2-phenylindole (DAPI, Fluka) at $0.5 \mathrm{mg} \mathrm{ml}^{-1}$ for $15 \mathrm{~min}$. The number of bacteria in 5 randomly selected fields of view was then estimated under an epifluorescence microscope (Axiophot, Zeiss; magnification $1500 \times_{i} \lambda_{\mathrm{Ex}}=359 \mathrm{~nm}, \lambda_{\mathrm{Em}}=441 \mathrm{~nm}$ ). Diatoms were counted in 10 randomly selected fields of view under a light microscope (Axiophot, Zeiss; magnification $1000 \times)$.

Juvenile mortality: After the larval bioassay, all nonsettled larvae were discarded and the dishes were filled with FSW and placed into an incubator $\left(T=25^{\circ} \mathrm{C}\right)$ for $5 \mathrm{~d}$. Juveniles were fed the alga Isochrysis galbana (concentration: $2.5 \times 10^{5}$ cells $\mathrm{ml}^{-1}$ ); water and alga in the dishes were changed every $24 \mathrm{~h}$. At the end of the experiment, the numbers of dead and live juveniles were determined. Juveniles were classified as dead when they did not respond to the gentle touch of a needle.

Analysis of laboratory data: For the statistical analysis, the numbers of swimming, metamorphosed and dead larvae were transformed into percentages of the total amount of larvae placed in each aquarium. The percentages were then arcsine-transformed. Zero values were replaced by a value of $4 \mathrm{n}^{-1}$ ( $\mathrm{n}=$ number of larvae in a single replicate) for the arcsine transformation (Zar 1996). The normality assumption was verified by the Shapiro-Wilk test (Shapiro \& Wilk 1965). Differences between experimental and control treatments were determined by 1-way ANOVA followed by the Tukey HSD post hoc test (Zar 1996). The densities of bacteria and diatoms were square-root-transformed to ensure normality of variance and then analysed with 1-way ANOVA followed by the Tukey HSD post hoc test.

\section{RESULTS}

\section{Field experiment}

Radiation measurements

The solar irradiances measured at midday above the water surface and at $4 \mathrm{~cm}$ depth below the surface did not change much over the course of the 4 mo experiment (Fig. 3). Only $46.5 \pm 2.0 \%$ of surface UV-A and $43.2 \pm 2.1 \%$ of UV-B reached the experimental tiles at the $4 \mathrm{~cm}$ water depth. During the time of the experiments, the mean UV-A and UV-B radiation at the $4 \mathrm{~cm}$ depth in the control treatment were $14.6 \pm 1.1 \mathrm{~W} \mathrm{~m}^{-2}$ and $0.5 \pm 0.1 \mathrm{~W} \mathrm{~m}^{-2}$, respectively. We did not detect any UV-A and UV-B radiation at the $4 \mathrm{~cm}$ depth in the no-UVR treatment. There was no UV-B radiation in the UV-A treatment, and the mean UV-A radiation at the depth of $4 \mathrm{~cm}$ was $13.4 \pm 0.9 \mathrm{~W} \mathrm{~m}^{-2}$.

\section{Species composition of the biofouling community}

A total of 16 species colonised the tiles: 3 green algal species (Chlorophyta: Ulotrichales, Ulva sp., Enteromorpha sp.; Cladophorales, Cladophora sp.), 2 brown algal species (Phaeophyta: Ectocarpales, Ectocarpus sp. and 1 unidentified filamentous brown alga), 2 red algal species (Rhodophyta: Ceramiales, Ceramium sp. and 1 unidentified encrusting alga) and 8 invertebrate species. These consisted of 2 polychaetes (Annelida: Polychaeta, namely Hydroides elegans and Spirobranchus sp.), 1 barnacle (Crustacea: Cirripedia, Balanus amphitrite), 3 bivalves (Mollusca: Bivalvia, Perna viridis, Anomia chinense and Modiolus comptus), and 2 bryozoans (Bryozoa: Cheilostomata, Bugula neritina and Schizoporella unicornis). During the experiments, the dominant species on the tiles were the algae Enteromorpha sp., Ectocarpus sp., Cladophora sp., the tube worm $H$. elegans and the green mussel $P$. viridis. All dominant species were present on the experimental and control plates, but in different proportions. The algae dominated in the control open treatments (the percentage of cover reached $90 \%$ ), while $H$. elegans and $P$. viridis were found predominantly in the no-UVR treatment (the percentage of cover reached 31.7 and $18.3 \%$, correspondingly). The percentage of cover of all other species aside from these dominant 5 species varied between 1.4 and $22.8 \%$ during the experiments.

\section{Effect of UV on the fouling community}

During the first $79 \mathrm{~d}(11 \mathrm{wk})$ of the experiment, the total cover of species on the tiles was around $50 \%$ and 

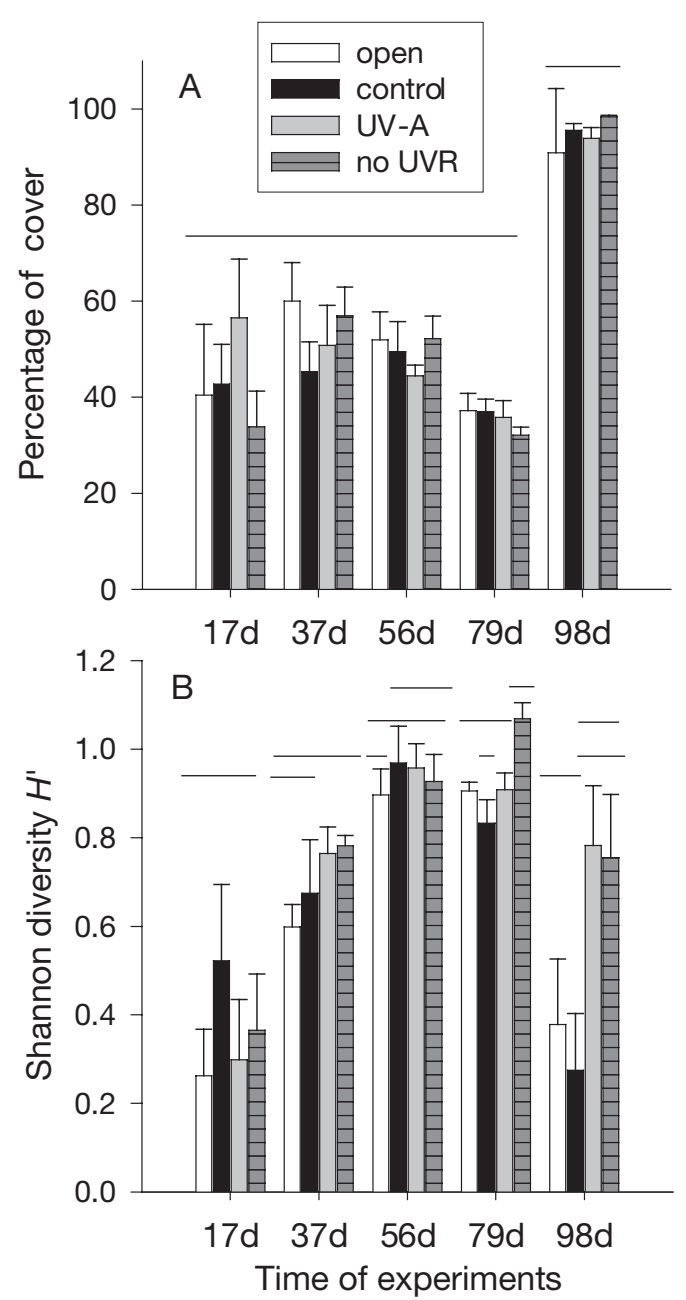

Fig. 4. (A) Total percentage of cover on the tiles from open boxes (open) and boxes with different filters (control; UV-A; no UVR), 17, 37, 56, 79 and $98 \mathrm{~d}$ from the start of the field experiments. (B) Shannon diversity index $\left(H^{\prime}\right)$ of fouling communities developed on the tiles from open boxes (open) and boxes with different filters (control; UV-A; no UVR), 17, 37, 56, 79 and $98 \mathrm{~d}$ from the start of the field experiments. On Day 79 of the experiments, we cut back the algae to a length of $1 \mathrm{~cm}$. Data are expressed as means + SE of 6 replicates. Means not joined by a horizontal line differed significantly

(ANOVA, HSD [least significant difference]: $\mathrm{p}<0.05$ ) increased 1.5- to 2-fold by the end of the experiment. The total proportions of algae and invertebrates covering the tiles changed over time, but did not differ significantly among radiation treatments (Fig. 4A, Table 1).

During the first $11 \mathrm{wk}$ of the experiments, the Shannon-Wiener diversity index $\left(H^{\prime}\right)$ was not affected by UVR (Fig. 4B). After $79 \mathrm{~d}$ (11 wk), the diversity of the fouling community was significantly greater (ANOVA: HSD, $p=0.04$ ) in the no-UVR treatment. By Day 98 (14 wk), after the algae were cut back, the diversity of the community $\left(H^{\prime}\right)$ was significantly higher in the noUVR (ANOVA: HSD, p = 0.02) and UV-A treatments (ANOVA: HSD, $\mathrm{p}=0.02$ ). Both UVR and time had significant effects on the diversity of community (Table 1). These effects changed over the duration of the experi-

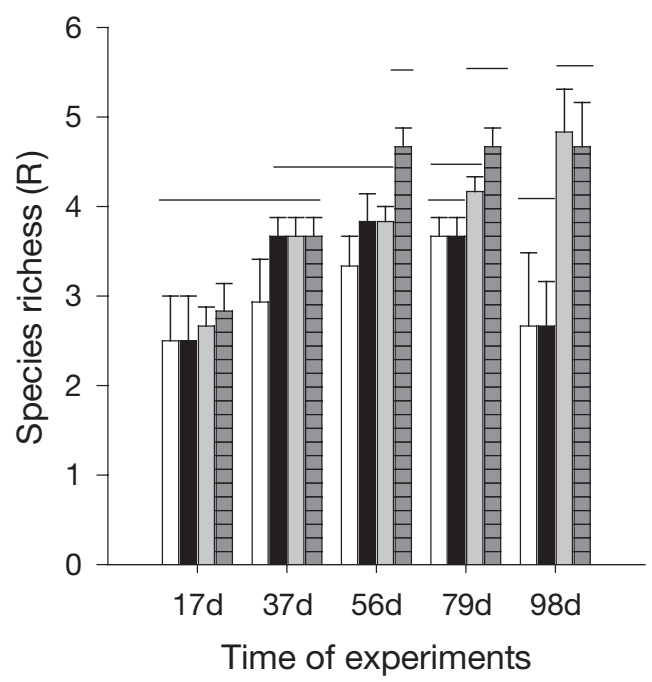

Fig. 5. Species richness (R) of fouling communities developed on the tiles from open boxes (open) and boxes with different filters (control; UV-A; no UVR), 17, 37, 56, 79 and $98 \mathrm{~d}$ from the start of field experiments. On Day 79 of the experiments, we cut back the algae to a length of $1 \mathrm{~cm}$. Data are expressed as means + SE of 6 replicates. Means not joined by a horizontal line differed significantly (ANOVA, HSD: $\mathrm{p}<0.05$ ). Colors and fills as in Fig. 4

Table 1. Repeated-measures ANOVA. The effect of UVR on percentage of cover, diversity $\left(H^{\prime}\right)$, species richness and wet weight during the field experiment $(0$ to $98 \mathrm{~d})$. Percentage of cover data were arcsine-transformed $(\mathrm{n}=6)$

\begin{tabular}{|c|c|c|c|c|c|c|c|c|c|}
\hline \multirow[t]{2}{*}{ Source } & \multirow[t]{2}{*}{$\mathrm{df}$} & \multicolumn{2}{|c|}{ Diversity $\left(H^{\prime}\right)$} & \multicolumn{2}{|c|}{ Percent cover } & \multicolumn{2}{|c|}{ Richness } & \multicolumn{2}{|c|}{ Wet weight } \\
\hline & & $F$ & $\mathrm{p}$ & $F$ & $\mathrm{p}$ & $F$ & $\mathrm{p}$ & $F$ & $\mathrm{p}$ \\
\hline Radiation $(R)$ & 3 & 4.06 & 0.021 & 0.48 & 0.699 & 12.00 & $<0.001$ & 1.83 & 0.174 \\
\hline Block & 5 & & & & & & & & \\
\hline Residuals & 15 & & & & & & & & \\
\hline Time $(T)$ & 4 & 29.27 & $<0.001$ & 52.33 & $<0.001$ & 11.97 & $<0.001$ & 26.34 & $<0.001$ \\
\hline$T \times R$ & 12 & 2.37 & 0.011 & 1.33 & 0.217 & 2.93 & 0.002 & 0.89 & 0.561 \\
\hline Residuals & 80 & & & & & & & & \\
\hline
\end{tabular}


ment, as indicated by the significant time by treatment interactions.

The lowest species richness was observed on the control plates at the start of experiments, and it was not different from other treatments (Fig. 5). By Day 56 and Day 79, the species richness was significantly higher in the no-UVR treatment than in all other treatments (ANOVA: HSD, $p=0.04$ ). After 98 d, i.e. after the algae were cut back, the species richness under both the UVA and no-UVR treatments was higher (ANOVA: HSD, $p=0.02$ and $p=0.01$, correspondingly) than that in the controls. The different radiation treatments affected species richness, and this effect changed over time (Table 1). Interactions between treatment and time were also observed.

Generally, the wet weight of communities developing on the tiles increased from the start to the end of the experiment (Fig. 6A). In our experiments, we did not find any effect of radiation treatment or time by
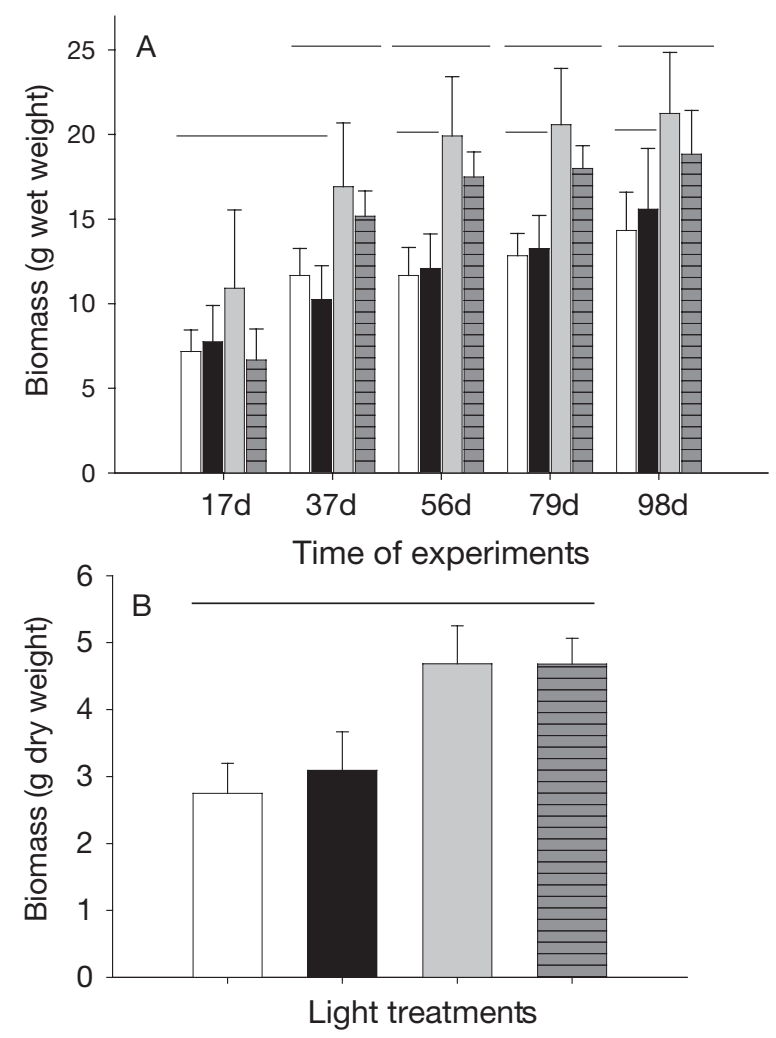

Fig. 6. Biomass of fouling communities developed on the tiles from open boxes (open) and boxes with different filters (control; UV-A; no UVR), during the field experiments. (A) Wet weight $(\mathrm{g})$ of the communities determined after $17,37,56,79$ and $98 \mathrm{~d}$ from the start of experiments. (B) Dry weight $(\mathrm{g})$ of the communities at the end of the experiment. On Day 79 of the experiments, we cut back the algae to a length of $1 \mathrm{~cm}$. Data are expressed as means + SE of 6 replicates. Means not joined by a horizontal line differed significantly (ANOVA, HSD: $p$ < 0.05). Color and fills as in Fig. 4 treatment interactions on the wet weight of the communities (Table 1). The dry weights on Day 98, after algae were cut back, were significantly different among the radiation treatments (ANOVA, $F_{3,15}=4.19$, $\mathrm{p}=0.02$ ), but the HSD post hoc test did not reveal any differences between the controls and the no-UVR and UV-A treatments (Fig. 6B).

On Day 37 and Day 98 of the experiment, the ANOSIM results revealed that the species composition of the fouling community was significantly (ANOSIM, $p<0.05$ ) different among the treatments (Table 2). The R-statistic values for these $2 \mathrm{~d}$, which demonstrate a relative separation value within groups, were 0.19 and 0.13, correspondingly. The SIMPER analysis for Day 37 revealed that 2 species of the macroalgae Ectocarpus sp. and Enetromorpha sp. accounted for $87 \%$ of the total Bray-Curtis dissimilarity among the fouling communities, while the invertebrate species accounted for $7 \%$ of the dissimilarity. The polychaete Hydroides elegans and the barnacle Balanus amphitrite were abundant in the no-UVR treatment, while the green alga Enteromorpha sp. and the brown alga Ectocarpus sp. were present predominantly in the UV-A and open treatments. After 98 d, 2 species of the invertebrates, Perna viridis and Balanus amphitrite, and 1 algal species, Cladophora sp., accounted for $>66 \%$ of the

Table 2. Results of ANOSIM (Global R, p) on species composition, and results of SIMPER on the distribution of single species to total dissimilarity in species composition (in percent) due to the radiation effect on Day 37 and Day 98. Contributions are averaged over all significant pair-wise treatment comparisons

\begin{tabular}{|lc|}
\hline & UVR effect \\
\hline After 17 d of experiments & $\mathrm{R}=0.073, \mathrm{p}=0.153$ \\
After 37 d of experiments & $\mathrm{R}=0.190, \mathrm{p}=0.004$ \\
Algae & $87.37 \%$ \\
Ectocarpus sp. & $58.05 \%$ \\
Enteromorpha sp. & $29.32 \%$ \\
Invertebrates & $6.52 \%$ \\
Balanus amphitrite & $5.29 \%$ \\
Hydroides elegans & $1.23 \%$ \\
After 56 d of experiments & $\mathrm{R}=0.044, \mathrm{p}=0.250$ \\
After 79 d of experiments & $\mathrm{R}=0.035, \mathrm{p}=0.239$ \\
After 98 d of experiments & $\mathrm{R}=0.127, \mathrm{p}=0.028$ \\
Algae & $56.67 \%$ \\
Cladophora sp. & $39.18 \%$ \\
Enteromorpha sp. & $9.74 \%$ \\
Unidentified filamentous brown algae & $4.71 \%$ \\
Unidentified encrusting red alga & $1.69 \%$ \\
Ulva sp. & $1.35 \%$ \\
Invertebrates & $33.21 \%$ \\
Perna viridis & $15.24 \%$ \\
Modiolus comptus & $12.28 \%$ \\
Balanus amphitrite & $5.69 \%$ \\
\hline
\end{tabular}


dissimilarity in the species composition among treatments (Table 2). The green algae Cladophora sp. and Enteromorpha sp. were found predominantly in the UV-A and open treatments, while the red (unidentified encrusting red alga) and brown algae (unidentified filamentous brown alga), as well as the molluscs Modiolus comptus and Perna viridis, settled predominantly in the no-UVR treatment.

\section{Laboratory experiments}

Because the polychaete Hydroides elegans is a dominant fouler species in Hong Kong surface waters (Wang \& Huang 1993, Qiu et al. 2003) and in our experiments it was present mostly in the reduced UVR treatments (Table 2), we preformed laboratory experiments in which we investigated the effect of UVR on larval settlement and the juvenile's post-settlement mortality. The maximal UVR (UV-A $=34.8 \mathrm{~W} \mathrm{~m}^{-2}$; UV$\mathrm{B}=1.44 \mathrm{~W} \mathrm{~m}^{-2}$ ) was observed at noon, while no UVR (UV-A, UV-B $=0 \mathrm{~W} \mathrm{~m}^{-2}$ ) was recorded at 18:00 h. During the experiments, the radiation doses for UV-A and UV-B were 3492 and $197 \mathrm{~kJ} \mathrm{~m}^{-2}$, respectively. The settlement of $H$. elegans larvae differed among treatments (ANOVA, $F_{2,12}=48.8, \mathrm{p}=0.0001$; Fig. $7 \mathrm{~A}$ ). The highest settlement rate was observed in the absence of UVR (no UVR and dark treatments); settlement in the control (full-spectrum sunlight) was 5 to 8 times lower. There were no significant differences (ANOVA: HSD, $p=0.54$ ) in the densities of the bacteria and diatoms on the experimental dishes. The mean density $( \pm \mathrm{SE})$ of bacteria on the dishes was $24 \times 10^{3} \pm 5 \times 10^{3} \mathrm{cells} \mathrm{mm}^{-2}$, and the mean density of diatoms was $60 \pm 12$ cells $\mathrm{mm}^{-2}$.

The survival of Hydroides elegans juveniles after $5 \mathrm{~d}$ differed among treatments (ANOVA, $F_{2,12}=21.2, \mathrm{p}=$ 0.0001; Fig. 7B). Survival was the highest in the dark and in the no-UVR treatment and lowest in the control (UVR + PAR).

\section{DISCUSSION}

In our field experiments, UVR did not affect the percentage of algal cover and of invertebrates or their weights on the tiles. In contrast, by Day 56 ( $8 \mathrm{wk})$, the species richness was significantly higher (ANOVA, $\mathrm{p}<$ 0.05) in the no-UVR treatment. Similarly, after $79 \mathrm{~d}$ (11 wk), the diversity of the fouling community was significantly greater in the no-UVR treatment. These results suggest that the fouling community was not initially affected by ultraviolet radiation, but it later became sensitive to UVR. The fouling communities in the open and control treatments were similar. The

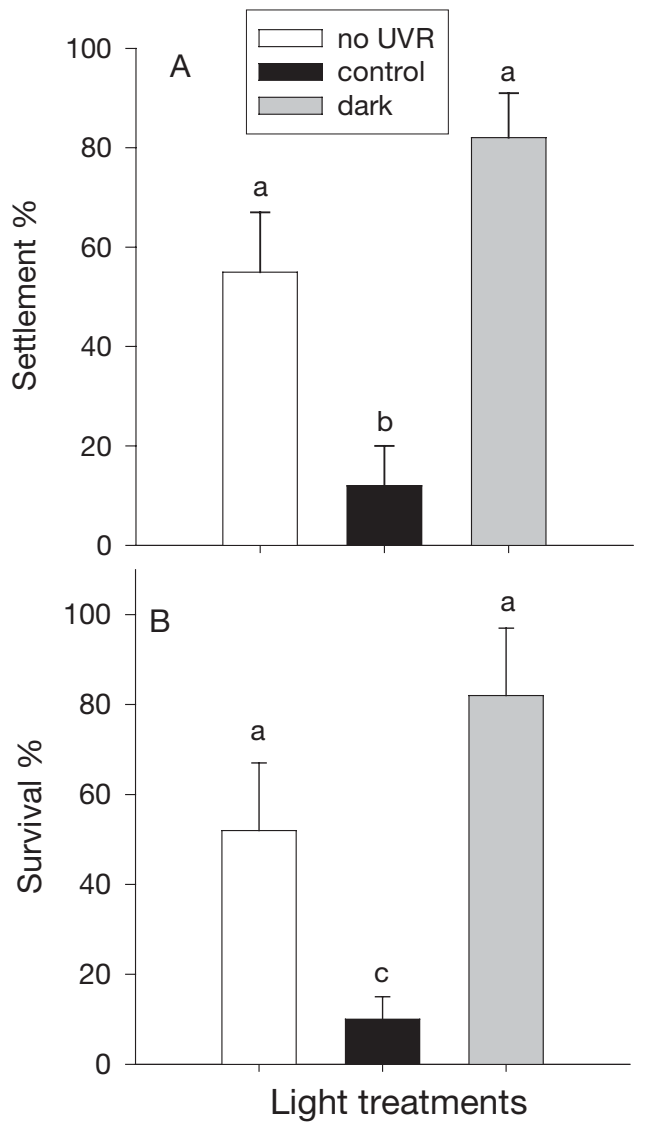

Fig. 7. Settlement (A) and survival (B) of the tubeworm Hydroides elegans in the outdoor experiments. The settlement of larvae on biofilmed Petri dishes was counted after the $12 \mathrm{~h}$. Survival was estimated on Day 5 of the experiment. Two filter sets (control and no UVR) were used. In the dark treatment, all Petri dishes were protected from UVR and PAR by a black cover. Data are expressed as means + SE of 5 replicates. Data that are significantly different according to an HSD test (ANOVA: $p<0.05$ ) are indicated by different letters above the bars

above-mentioned difference in community development was therefore the result of UVR exposure, not an artefact of the presence of filters.

The absence of an effect from UVR at the start of our experiments and the inhibition of longer developed communities by UVR may be explained by 3 mechanisms. First, early colonisers in our experiments may have been less sensitive to UVR than later colonisers. During the first $37 \mathrm{~d}$ of our experiment, the algae Enteromorpha sp. and Ectocarpus sp. were the dominant species on the tiles. The green alga Cladophora $\mathrm{sp}$. dominated at the end of the experiments. Other species of algae and invertebrates appeared on the tiles mostly after Day 56. Algal species of the genera Enteromorpha, Ectocarpus and Cladophora are frequently observed in coastal waters exposed to high 
solar radiation levels, and the abundance of such species near the surface is partly due to their high UVR tolerance (Santas et al. 1998a). Second, the low number of fouling species, usually 2 to 3, during the first week of the experiments, as well as the fluctuation in their distribution on a particular tile (e.g. percent of cover of Enteromorpha sp. on the control tiles varied from 4 to $67 \%$ ), might camouflage a UVR effect. Third, the UV effect may match with the seasonal radiation flux and the temporal variation of the water turbidity. Unfortunately, we did not monitor turbidity during our experiment. The surface UVR levels and the belowsurface UVR levels, however, did not change significantly during the experimental period (Fig. 3).

After $5 \mathrm{wk}$ (37 d) and at the end of the field experiment (14 wk), the composition of the early successional communities was significantly affected by UVR (Table 2; ANOSIM, p < 0.05), but the relative separation value $(\mathrm{R})$ within treatments was $<0.2$. Some invertebrate species, like Balanus amphitrite, Hydroides elegans, juveniles of Perna viridis and Modiolus comptus, as well as the algae Enteromorpha sp., Ectocarpus sp., Cladophora sp., Ulva sp. and the unidentified brown and red algae, were responsible for the dissimilarity between communities developed in the UVR (control) and no-UVR treatments. Harmful UV effects on invertebrate and algal species may have favoured some species and decreased colonisation of other species. For example, after $5 \mathrm{wk}$ the percentage of cover of the green alga Enteromorpha sp. and the brown alga Ectocarpus sp. was higher in the control treatment. In contrast, the percentage of cover of $H$. elegans and $B$. amphitrite at the start of the experiments and the percentage of cover of $P$. viridis, $B$. amphitrite and $M$. comptus at the end of the experiments were higher under the no-UVR treatment. Therefore, changing the UVR may cause shifts in species composition and community structures.

After $79 \mathrm{~d}$ (11 wk) algae grew intensively in all treatments and reduced the water exchange in the boxes. We therefore cut the algae back to a length of $1 \mathrm{~cm}$. This artificial procedure may have caused changes in the community structures and may have sharpened or blurred the effect of UVR on the fouling communities. UV-tolerant species, such as the green algae Cladophora sp. and Enteromorpha sp. as well as the brown alga Ectocarpus sp., might provide special shelter from UVR for other species. Cutting back these algae could have allowed us to override the influence of UV-tolerant species and strengthen the effect of UVR on the fouling community at the end (14 wk) of the field experiment. However, before starting this procedure, we observed the inhibitive effect of UVR on the species richness in the communities. Therefore, our results clearly demonstrated that changes in UVR lead to subsequent changes in early successional fouling communities in shallow waters.

We conducted our study only 3 mo on the early successional biofouling community in shallow waters. The choice of $4 \mathrm{~cm}$ depth was conditioned by our preliminary results in which only $25 \%$ of UV-A and $6 \%$ of UV$B$ reached the depth of $1 \mathrm{~m}$. It is likely that UVR has no effects on the fouling communities in deeper waters. In tropical waters, the colonisation and succession of biofouling communities proceeds very rapidly (Huang \& Mark 1982, Huang et al. 1999, Qiu et al. 2003, Dobretsov et al. 2004) in comparison with such colonisation and succession in temperate waters. It is possible that the effects of UVR on fouling communities will continue or will diminish over a longer experimental period. The effects of UVR on the formation of late successional biofouling communities at different depths need to be investigated in the future.

Other studies have demonstrated that UVR has short-term effects on the macroalgal biomass (Santas et al. 1998a, Lotze at al. 2002) and the periphyton biomass (Santas et al. 1996, 1998b). For example, exposure to enhanced UV-B radiation reduced the productivity of filamentous algal assemblages grown in laboratory mesocosms, but the effect diminished after 6 wk (Santas et al. 1998a). UVR inhibited the biomass of Mediterranean and Caribbean diatom communities during 2 to $3 \mathrm{wk}$ of experiments, but had no effect on the communities after 4 wk (Santas et al. 1996, 1998b). Similarly, the biomass and cover of the early successional brown alga Pilayella littoralis were strongly suppressed by UV radiation (Lotze et al. 2002). It was proposed earlier that some UV-tolerant species grown at the later successional communities can provide protective shading for UVR-sensitive species, thus buffering harmful UVR effects at the community level (Santas et al. 1998a, Lotze et al. 2002, Molis \& Wahl 2004). For example, off the coast of Namibia, the red alga Ceramium sp. produced a canopy which protected UVsensitive species, such as Chylocaldia capensis. The mussel Mytilus edulis and the brown alga Petalonia fascia are more tolerant to UV stress and might reduce the effect of UVR on other UV-sensitive species (Lotze et al. 2002).

In our field experiments, the percentage of cover of some species, such as Hydroides elegans, was higher in the no-UVR treatment. To study this phenomenon, we conducted an outdoor laboratory experiment with ambient sunlight, in which we investigated the settlement and post-settlement mortality of $H$. elegans. We found that UVR inhibits both settlement and postmetamorphic survival of $H$. elegans. The highest settlement rate was observed in the absence of UVR (Fig. 7). In our experiments, the microbial communities in all treatments were uniform, which suggests that 
settlement differences did not result from the differences in the biofilm. In our experiments, approximately $15 \%$ of larvae settled under full sunlight (PAR + UV-A + UV-B), but most of them died over the following $5 \mathrm{~d}$. The results of our outdoor experiments with $H$. elegans support the results of our field study: the abundance of $H$. elegans in both cases was inhibited by UVR. Apparently, in our experiments, the low percentage of cover of $H$. elegans in a control treatment may be explained not only by species competition, but also by inhibition of recruitment and by high mortality among the juveniles.

Inhibition of larval settlement (Baker 1995, Bingham \& Reitzel 2000, Chiang et al. 2003) and spore germination (Santas et al. 1998a) by UVR has previously been observed. In outdoor experiments, Baker (1995) demonstrated the inhibitory effects of UVR on the settlement of the reef coral Pocillopora damicornis. Similar results were reported for $P$. damicornis in field experiments (Kuffner 2001). Bingham \& Reitzel (2000) reported that ambient UV-A significantly damaged adults and embryos of the tunicate Corella inflata. UVA also had a major impact on the development of embryos of the tunicate when the embryos were either completely exposed or held within the adult brood chamber. In laboratory experiments, enhanced UV-B radiation induced ocular damage in larvae of the barnacle Balanus amphitrite, thereby impairing the phototactic behaviour of the naupliar larvae and reducing the settlement success of the cypris larvae (Chiang et al. 2003).

How does UVR inhibit Hydroides elegans larval settlement? First, UVR might directly kill larvae. In our study, we did not observe the mortality of larvae under UVR treatment; however, this may indicate that UVR has a sub-lethal effect or inhibits larval settlement in other ways. Second, larval receptors necessary for settlement might be damaged by elevated radiation. It has been demonstrated that UV-B radiation caused significant disruptions of rhabdomeres (photosensitive cells) in the naupliar eyes of larvae of the barnacle Balanus amphitrite (Chiang et al. 2003). Because receptors other than eyes may also be involved in larval settlement, it is possible that damage of the ocular receptors alone may not fully explain the reduction of settlement caused by UVR. Finally, chemical cues, which are necessary for larval settlement, might be destroyed by UVR. It has been demonstrated that most larvae require specific chemical cues for settlement (see reviews: Scheltema 1974, Pawlik 1992, Rodriguez et al. 1993). Biofilms, which mainly consist of bacteria and diatoms, are known to induce settlement of $H$. elegans (Hadfield et al. 1994, Qiu \& Qian 1997, Unabia \& Hadfield 1999, Lau \& Qian 2001, Harder et al. 2002, Lau et al. 2003). After monospecies and multispecies biofilms were treated with UVR, the inductive effects of the biofilm became inhibitive (Unabia \& Hadfield 1999, Lau et al. 2003); this effect is dependent on the amount of live bacterial cells in the biofilm (Lau \& Qian 2001). In our experiments, we did not estimate the number of dead and live cells in the biofilm, but it is conceivable that UVR may kill bacteria and diatoms and subsequently decrease the inductiveness of the biofilm. Therefore, it is possible that UVR inhibited $H$. elegans settlement both by damage of settlement receptors and by destruction of the chemical cues associated with biofilms. However, the actual mechanisms need to be explored further through additional experiments.

In summary, our results show that UVR had no detectable effect on the inicial development of biofouling communities, but it affected the diversity, species richness and composition of later stages of early successional fouling communities. UVR may cause different patterns of larval settlement and post-settlement mortality of fouling species. Overall, species-specific and life-stage-specific sensitivities towards UVR may lead to changes in the composition of rocky-shore and shallow-water fouling communities.

Acknowledgements. We are most thankful to the staff in the Hong Kong University of Science and Technology workshop for their help in the construction of the experimental set-up. We also thank the students in the Coastal Marine Laboratory of the Hong Kong University of Science and Technology for their essential help during the measurements. We thank Dr. L. Gosselin (Canada) and Dr. D. Wethey (USA) for helpful comments on the manuscript. We thank Dr. V. Unkefer (Hong Kong) for editorial work on the manuscript. This work was supported in part by the Proklima International (GTZ), Windhoek, Namibia, to M.W. and by grants (CA00/01.Sc01, HKUST6119/01M， HKUST6100/02M), AOE/P-04/04-2 to P.-Y.Q.

\section{LITERATURE CITED}

Bailey CA, Neihof RA, Tabor PS (1983) Inhibitory effect of solar radiation on amino acid uptake in Chesapeake Bay bacteria. Appl Environ Microb 46:44-49

Baker AC (1995) Solar UV-A inhibition of planula larvae in the reef-building coral Pocillopora damicornis. In: Gulko D, Jokiel PL (eds) Ultraviolet radiation and coral reefs. Hawaii Institute of Marine Biology Tech Rep 41. Sea Grant, Honolulu, HI, p 149-163

Bingham BL, Reitzel AM (2000) Solar damage to the solitary ascidian, Corella inflata. J Mar Biol Assoc UK 80:515-521

Bornman JF, Teramura AH (1993) Effects of ultraviolet-B radiation on terrestrial plants. In: Young AR, Bjoern LO, Moan J, Nultsch W (eds) Environmental UV photobiology. Plenum Press, New York, p 427-471

Bothwell ML, Sherbot D, Roberge AC, Daley RJ (1993) Influence of natural ultraviolet radiation on lotic periphytic diatom community growth, biomass accrual, and species composition: short-term versus long-term effects. J Phycol $29: 24-35$ 
Bothwell ML, Sherbot DMJ, Pollock CM (1994) Ecosystem response to solar UVB-radiation: influence of trophic-level interactions. Science 265:97-100

Bryan JP, Kreider L, Qian PY (1997) Settlement of the polychaete Hydroides elegans on surfaces of the cheilostome bryozoan Bugula neritina: evidence for a chemically mediated relationship. J Exp Mar Biol Ecol 220:171-190

Chalker-Scott L, Scott JD, Dunning C, Smith K (1992) Effect of ultraviolet-B radiation $(280-320 \mathrm{~nm})$ on survivorship of zebra mussel larvae (Dreissena polymorpha): a potential control strategy. J Shellfish Res 11:221

Chiang WL, Au DWT, Yu PKN, Wu RSS (2003) UV-B damages eyes of barnacle larvae and impairs their photoresponses and settlement success. Environ Sci Technol 37: 1089-1092

Clarke KR, Ainsworth M (1993) A method of linking multivariate community structure to environmental variables. Mar Ecol Prog Ser 92:205-219

Clarke KR, Gorley RN (2001) PRIMER v5: user manual/tutorial. PRIMER-E, Plymouth

Dobretsov S, Dahms HU, Qian PY (2004) Antilarval and antimicrobial activity of waterborne metabolites of the sponge Callyspongia (Euplacella) pulvinata: evidence of allelopathy. Mar Ecol Prog Ser 271:133-146

Franklin LA, Forster RM (1997) The changing irradiance environment: consequences for marine macrophyte physiology, productivity and ecology. Eur J Phycol 32:207-232

Hadfield MG, Unabia CC, Smith CM, Michael TM (1994) Settlement preferences of the ubiquitous fouler Hydroides elegans. In: Thompson MF, Sarojini R, Nagabhushanam R (eds) Recent developments in biofouling control. Oxford \& IBH, New Delhi, p 65-74

Harder T, Lam C, Qian PY (2002) Induction of larval settlement in the polychaete Hydroides elegans by marine biofilms: an investigation of monospecific diatom films as settlement cues. Mar Ecol Prog Ser 229:105-112

Hoag H (2003) UV blinds barnacles. Nat News, available at www.nature.com/nsu/030224/030224-4.html

Huang ZG, Mark PMS (1982) Studies on biofouling in Tolo Harbour. In: Morton B, Tseng (eds) Proceedings of the 1st international marine biological workshop: the marine flora and fauna of Hong Kong and Southern China. Hong Kong University Press, Hong Kong, p 767-787

Huang Z, Li Z, Morton B, Leung TY (1999) Biofouling of cage macroculture zones in the southern waters of Hong Kong. Asian Mar Biol 16:77-99

Kuffner IB (2001) Effects of ultraviolet (UV) radiation on larval settlement of the reef coral Pocillopora damicornis. Mar Ecol Prog Ser 217:251-261

Lau SCK, Qian PY (2001) Larval settlement in the serpulid polychaete Hydroides elegans in response to bacterial films: an investigation of the nature of putative larval cue. Mar Biol 138:321-328

Lau CK, Harder T, Qian PY (2003) Induction of larval settlement in the serpulid polychaete Hydroides elegans (Haswell): role of bacterial extracellular polymers. Biofouling 19:197-204

Lotze HK, Worm B, Molis M, Wahl M (2002) Effect of UV radiation and consumers on recruitment and succession of a marine macrobenthic community. Mar Ecol Prog Ser 243: 57-66

Molis M, Wahl M (2004) Transient effects of solar ultraviolet radiation on the diversity and structure of a field-grown

Editorial responsibility: Otto Kinne (Editor-in-Chief), Oldendorf/Luhe, Germany epibenthic community at Lüderitz, Namibia. J Exp Mar Biol Ecol 302:51-62

Molis M, Lenz M, Wahl M (2003) Radiation effects along a UV-B gradient on species composition and diversity of a shallow-water macrobenthic community in the western Baltic. Mar Ecol Prog Ser 263:113-125

Pawlik JR (1992) Chemical ecology of the settlement of benthic marine invertebrates. Oceanogr Mar Biol Annu Rev 30:273-291

Pechenik JA, Qian PY (1998) Onset and maintenance of metamorphic competence in the marine polychaete Hydroides elegans Haswell in reponse to three chemical cues. J Exp Mar Biol Ecol 226:51-74

Qiu JW, Qian PY (1997) Combined effects of salinity, temperature and food on early development of the polychaete Hydroides elegans. Mar Ecol Prog Ser 152:79-88

Qiu JW, Thiyagarajan V, Leung AWY, Qian PY (2003) Development of a marine subtidal epibiotic community in Hong Kong: implications for deployment of artificial reefs. Biofouling 19:37-46

Rodriguez CA, Browman HI, St-Pierre JF (1993) High survival of neustonic zoea I larvae of American lobster Homarus americanus following short-term exposure to ultraviolet radiation (280 to $400 \mathrm{~nm}$ ). Mar Ecol Prog Ser 193:305-309

Santas R, Gaeder DP, Lianou C (1996) Effects of solar UV radiation on diatom assemblages of the Mediterranean. Photochem Photobiol 64:435-439

Santas R, Korda A, Lianou C, Santas P (1998a) Community responses to UV radiation. 1. Enhanced UVB effects on biomass and community structure of filamentous algal assemblages growing in a coral reef mesocosm. Mar Biol 131:153-162

Santas R, Santas Ph, Lianou Ch, Korda A (1998b) Community responses to UV radiation. 2. Effects of solar UVB on fieldgrown diatom assemblages of the Carribean. Mar Biol 131:163-171

Scheltema RS (1974) Biological interactions determining larval settlement of marine invertebrates. Thalassia Jugoslav 10:263-296

Searles PS, Flint SD, Caldwell MM (2001) A meta-analysis of plant field studies simulating stratospheric ozone depletion. Oecologia 127:1-10

Shapiro SS, Wilk MB (1965) An analysis of variance test for normality (complete samples). Biometrika 52:591-611

Unabia CRC, Hadfield M (1999) Role of bacteria in larval settlement and metamorphosis of the polychaete Hydroides elegans. Mar Biol 133:55-64

Underwood AJ (2001) Experiments in ecology: their logical design and interpretation using analysis of variance. Cambridge University Press, Cambridge

Wang JJ, Huang ZG (1993) Fouling polychaetes of Hong Kong and adjacent eaters. Asian Mar Biol 10:1-12

Warwick RM, Clarke KR (1995) New 'biodiversity' measures reveal a decrease in taxonomic distinctness with increasing stress. Mar Ecol Prog Ser 129:301-305

Weincke C, Gomez I, Pakker H, Flores-Moya A, Altamirano M, Hanelt D, Bischof K, Figueroa FL (2000) Impact of UVradiation on the viability, photosynthetic characteristics and DNA of brown algal zoospores: implications for depth zonation. Mar Ecol Prog Ser 197:217-229

Willamson CE (1996) Effects of UV radiation on freshwater ecosystems. Int J Environ Stud 51:245-256

Zar JH (1996) Biostatistical analysis, 3rd edn. Prentice Hall International, Engelwood Cliffs, NJ

Submitted: July 13, 2004; Accepted: December 14, 2004

Proofs received from author(s): March 24, 2005 